\title{
Apprenticeship training and the business cycle
}

\author{
Samuel Muehlemann ${ }^{a, *}$, Stefan C. Wolter ${ }^{b}$, Adrian Wüest $^{c}$ \\ ${ }^{a, b}$ Department of Economics, University of Bern \\ ${ }^{c}$ Federal Office for Professional Education and Technology, Bern
}

\begin{abstract}
Dual apprenticeship training is a form of education at the upper secondary level, taking place in vocational school as well as in firms. Therefore, the willingness of firms to offer apprenticeships is a necessity for the functioning of this part of the educational system. Although it is likely that the economic climate has an impact on the firm's supply of apprenticeships, little is known so far about the impact of the business cycle on the number of apprenticeship programs offered. Using panel-data of Swiss cantons from 1988-2004, we find that the influence of the business cycle is statistically significant, but small in size. Instead, supply of apprenticeship programs is driven to a much greater extent by demographic change.
\end{abstract}

Keywords: Apprenticeship training, high school enrollment, business cycle

\section{Introduction}

Dual training programs, i.e. firm-based provision of training in combination with formal education in vocational schools, can be regarded as a market-driven type of education, since firms are free to chose whether they want to engage in training, and because apprentices spend more than half of their time at the workplace, engaged not only in training activities but also in productive work. While full-time general education may not be expected to depend on the economic climate in the short run, this has not necessarily to be true for firm-based training. How dual apprenticeship programs might be influenced by business cycles is an important and also policyrelevant research question for countries with a high share of dual vocational education. In Switzerland, but similarly also in Germany, more than half of each cohort of school leavers enroll in a dual apprenticeship program. Put differently, more than half of a cohort's educational outcome can potentially be affected by business cycle movements. Apprenticeship programs in Switzerland, but also in other European countries such as Germany, Austria, Denmark or the Netherlands are designed in a way that firms are obliged by apprenticeship contracts to provide formal training to their apprentices at the workplace. This means that a firm is required to make a financial investment in their apprentices, without being able to unilaterally terminate a

\footnotetext{
*Corresponding author: Department of Economics, Schanzeneckstrasse 1, CH-3001 Bern. E-mail: samuel.muehlemann@vwi.unibe.ch. We would like to thank the Swiss Federal Statistical Office, particularly Anton Rudin, for the provision of the data used in the analysis.
} 
training contract for several years. As a consequence, firms might refrain from such financial investments if the business outlook is bad.

For our empirical analysis we use data on new apprenticeship contracts in all 26 Swiss cantons from the years 1988-2004. The federalistic nature of the Swiss education system makes such an analysis meaningful, since the availability of alternatives to vocational education, i.e. full-time general education programs, but also demographic changes, industry structure and therefore business cycles vary greatly between different cantons. This in turn can have an impact on the dual apprenticeship system, because the average ability of youth applying for apprenticeships may be lower if general education programs were to attract the more able pupils. Making use of the panel structure of our data, we apply first-differences estimators and find that enrollment in apprenticeship programs significantly depends on our measures of the business cycle, the unemployment rate and the lagged change in cantonal income growth. As expected, an increase in the unemployment rate has a negative effect on new apprenticeship contracts, whereas a change in the growth rate cantonal income has a positive effect. However, the economic significance of these effects is rather small. Conversely, our results show that demographic fluctuations in the relevant cohort of school leavers at age 16 is a much more important factor in explaining fluctuations in apprenticeships. In addition, we find that the provision of upper secondary high school education, which grants access to university, increases steadily during times when more young people leave compulsory schooling, but enrollment does not become more restricted in times of negative population growth.

This article is organized as follows: The next section provides an overview of the relevant literature. Section 3 outlines the functioning of the Swiss apprenticeship system. Section 4 provides information about our data set and some descriptive statistics. The econometric modeling is given in section 5, and section 6 presents the results. The final section concludes.

\section{Related literature}

The aim of this section is to provide a short summary of the relevant theoretical and empirical literature of business cycle effects on apprenticeship training. Brunello (2009), in a recent OECD survey, provides an extensive treatment of the literature on business cycle effects on apprenticeship training and other forms of training, hence we will focus solely on the most relevant papers for our own empirical analysis in this article.

Business cycle effects on apprenticeship training may be at least twofold: On the one hand, the firm's demand for skilled workers is usually lower during an economic downturn, which might go hand in hand with a reduction in the demand for apprentices, in the case where apprenticeship programs are an integral part of the firm's recruitment strategy (Lindley, 1975, Merrilees, 1983, Stevens, 1994, Brunello $\&$ Medio, 2001). A firm can find it optimal to train apprentices if retaining former trainees as skilled workers after completion of training is less expensive compared 
to hiring skilled workers on the external labor market. Therefore, if a firm needs less skilled workers in the short run, it could be expected that the extent of apprenticeship training will be reduced. ${ }^{1}$ However, since apprenticeship programs typically last between three and four years, business cycle fluctuations might not have a strong impact on the provision of training, because firms should expect that the economy will have already recovered by the time the apprenticeship has finished. On the other hand, business cycle fluctuations can also affect the firm's benefit of using apprentices in their production processes. In times of prosperity, when the order books are filled, there may be a lot of skilled as well as unskilled work that can be allocated to apprentices. Given a relatively low salary of apprentices, a firm could have an incentive to expand their training activities in the short-run due to a production motive (Lindley, 1975). However, Merrilees (1983) argued that firms will not adjust their demand for apprentices immediately to increase output during an economic boom. A firm might instead prefer to switch the use of trainers from training apprentices to productive activities in order to increase output. Furthermore, it is likely the case that apprentices are initially not very productive because they first need to be trained in the relevant tasks to carry out skilled work. Summing up, theoretical considerations imply that while there are potentially important effects of business cycles, there are also countervailing effects at play which possibly reduce the overall effects of economic fluctuations on the supply of apprenticeships by firms. It is therefore an empirical matter to determine whether these effects are of economic importance both to firms and policy makers.

There are a number of empirical studies that provide some evidence that fewer new apprenticeship positions are offered during an economic downturn or if unemployment rates are high. For Switzerland, the only study so far has been carried out by Schweri and Müller (2008), who find a (small) positive effect of average GDP growth (previous three years) on the firm's propensity to train and on the apprenticeship ratio in Switzerland. Dietrich and Gerner (2007) find that German firms react sensitively to changes in (self-reported) short-term business expectations using (unbalanced) IAB Establishment Panel data for the periods 1993-2003; a 1\%-point increase in the firm's expected business volume increases the firm's growth rate of new apprenticeships by $0.35 \%$-points.

For the UK, Hart (2005) finds that less apprenticeships have been offered during the Great Depression, however, firms seemed to lay off the relatively more expensive journeyman earlier compared to apprentices. Merrilees (1983) found a negative relationship between new apprenticeship contracts and unemployment and a positive correlation with output for the periods 1963-1979 in the UK.

For Scandinavian countries, Askilden and Nilsen (2005) provide evidence that apprenticeships decrease with (current) unemployment in Norway. For the same

\footnotetext{
${ }^{1}$ It is a common finding in many industrialized countries that youth unemployment increases more compared to the other workforce during an economic downturn (Gielen \& van Ours, 2006), which is in support of the hypothesis above. However, this might also be due to labor market regulations demanding firms to apply the "last-in-first-out" rule.
} 
country, Brunello (2009) shows the (bivariate) negative relationship of apprentices to pupils in secondary education. In addition, Westergaard-Nielsen and Rasmussen (1999) find that firm's demand for apprentices is positively related to demand for skilled labor in Denmark, which is in line with the results above.

Business cycle effects can not only influence the firm's offer of apprenticeships, but also the quit rate of individual apprentices. Bilginsoy (2003) finds for the United States, that apprentices are more likely to leave an apprenticeship program if unemployment is low, since outside options increase if the labor market is tight. However, in Switzerland, apprenticeship contracts are binding and cannot be terminated unilaterally. ${ }^{2}$ Therefore, this line of argument is not of great importance for the Swiss case. However, enrollment in apprenticeships might be lower for school-leavers at the lower end of the ability distribution, because unskilled labor as an outside option becomes more attractive if corresponding wages increase during an economic boom.

Finally, it should be noted that the motivation for a firm to provide apprenticeship training may be very different from on-the-job training of the existing skilled workforce. Bassanini et al. (2007) show that workplace training in Europe (excluding apprenticeships) positively depends on the unemployment rate, which is not in line with the existing empirical findings on apprenticeship training. They interpret this result such that firms are more likely to reorganize and restructure during slack times. ${ }^{3}$ Bassanini and Brunello (2007) find that their measure of the business cycle, i.e. $\log$ hours worked, is negatively related to proportion of a firm's employees receiving training. Yet other studies on general training find a negative association between unemployment and training, similarly to the literature on apprenticeship training (Majumdar, 2007). Relating these results to the case of apprenticeship training, one should keep in mind the different strategy of the two training schemes. While general workplace training is aimed at updating certain skills, the goal of apprenticeship training is to equip young adults with the necessary skills to become a skilled worker in the trained occupation. Furthermore, while workplace training usually applies to the existing workforce, the decision to train apprentices or not involves a new hire. Hence, firms are more likely to retrain the existing workforce and avoid firing costs, as well as the costs to rehire new workers in the next boom period. ${ }^{4}$ Therefore, it might indeed be efficient for a firm to keep their existing workforce and provide extra training if business is slow; however, we would not expect firms to hire more apprentices during a recession.

\footnotetext{
${ }^{2}$ Except for special circumstances that prohibit a regular completion of the training program. In such a case, the cantonal authorities must be contacted by law to terminate an apprenticeship contract.

${ }^{3}$ However, they also find that firms are less likely to provide training if the output gap of a firm is large, i.e. output is below potential output, which is at odds with the previous result, because output and unemployment are usually negatively related.

${ }^{4}$ Blatter et al. (2008) show that hiring costs for skilled workers in Switzerland are substantial, averaging roughly one quarter of wage payments.
} 


\section{The apprenticeship system in Switzerland}

The apprenticeship system in Switzerland has a long tradition and has proven itself successful in providing young people with theoretical education and practical training, such that they become productive participants in the labor market; the youth unemployment rate in Switzerland is one of the lowest among OECD countries. This might partly be due to the features of the Swiss apprenticeship system, which enables a large share of young people to obtain a degree at the third level of the International Standard Classification of Education (ISCED). Similar apprenticeship systems exist in Germany, Austria, Denmark and the Netherlands. ${ }^{5}$ While this paper focuses on the duality of apprenticeship training, where apprentices have a contract with their training firm and attend vocational school, entirely school-based apprenticeship programs exist as well. However, dual apprenticeship programs in Switzerland are the most widely applied approach to educating students at the upper-secondary level. Each year, roughly $60 \%$ of a cohort of school-leavers who pursue some kind of postcompulsory schooling enroll in a dual apprenticeship training program, which is typically at the age of 15 or 16 . School-based apprenticeships amount to roughly $10 \%$ of all apprenticeship contracts. There are some 235 different training occupations to choose from, which require either two, three or four years of training (Federal Office for Professional Education and Technology, 2008). Before the start of training, the apprentice and the firm are obliged to sign a binding contract, which determines the quantity and quality of training provided by the firm, apprentice pay throughout the years of training and further obligations between the two parties. ${ }^{6}$ Furthermore, the contract cannot be terminated unilaterally by either party and ends automatically by completion of training. This implies that a training firm has not legal possibility to keep the apprentices as a skilled workers (at a possibly low wage) after training. Retention rates in Switzerland are rather low, with only somewhat more than one third of apprentices still being employed in the training firm one year after training.

During the course of a program, an apprentice usually spends 1-2 days in a stateorganized (and financed) vocational school, receiving general education as well as theoretical knowledge about occupation-related issues. There are exams in the vocational schools throughout training period, which require passing grades. In addition, there is an extensive final exam at the end of the apprenticeship. Successful graduates will be given a national certificate, attesting the apprentice a professional qualification to perform skilled work in the respective occupation. However, in addition to formal education at the vocational school, an apprentice receives further formal training at the workplace throughout the training program. It should be noted that training personnel in the firm needs to have successfully completed apprenticeship instruction courses itself (Hoeckel et al., 2009). This in turn should guarantee that

\footnotetext{
${ }^{5}$ Ryan (1998) provides an international perspective on the performance of apprenticeship systems with respect to labor market outcomes

${ }^{6}$ See Dustmann \& Schönberg (2007) on the importance of the firm's commitment to externally validated skills standards.
} 
certain quality standards for firm-based training are met. In-firm training comes at a cost for the employer, however, in Switzerland, firms can generate a benefit from the productive contribution of apprentices, which on average outweighs the training expenditures (Wolter et al., 2006). Independently whether a firm has to incur net costs or can generate a net benefit of training, the economic climate will influence the cost-benefit ratio and thereby the probability that a firm will offer apprenticeships (Muehlemann et al., 2007).

\section{Data}

Our data set includes information about enrollment in apprenticeships and enrollment in high school education at the upper secondary level, which grants access to university, from 1988 to 2004 for all 26 cantons in Switzerland. In addition, we also have variables related to the business cycle within each canton, i.e. the cantonal unemployment rate and the growth rate of the cantonal income, as well as the overall population and the population of school leavers at age 16 .

The variable on new enrollment in high schools is defined by the pupil's canton of residence, and not by the canton where the high school is situated. This is of some importance, as not all cantons have their own high schools, yet pupils can enroll in high schools in neighboring cantons. The definition of the cantonal income has changed twice within our period of interest, therefore the calculated figures are not directly comparable across the whole time period. However, since we will use growth rates in our analysis and not income levels, this should not have a significant impact on our estimates. ${ }^{7}$ Descriptive statistics of all variables used in the analysis are provided in Table 1.

Table 1: Descriptive statistics

\begin{tabular}{lrrrr}
\hline Variable & Mean & Std. Dev. & Min & Max \\
\hline Apprenticeships & 2260.233 & 2376.531 & 95 & 10547 \\
High school enrollment & 684.057 & 694.948 & 9 & 2916 \\
Unemployment rate & 2.529 & 1.840 & 0.0 & 7.8 \\
Cantonal income growth rate & 2.919 & 4.614 & -17.0 & 41.6 \\
Population age 16 & 3154.830 & 3060.453 & 181 & 12974 \\
Population (all ages, in '000) & 271.185 & 279.672 & 13.333 & 1261.810 \\
\hline
\end{tabular}

Notes: Summary statistics correspond to averages across 26 cantons from the years 1988 - 2004.

\footnotetext{
${ }^{7}$ For the two transition phases, we have imputed the national GDP growth rate as an approximation for each cantonal income growth in order to circumvent any biases that might arise due to the change in the definition of cantonal income.
} 


\section{Econometric modeling}

The absolute level $a$ of enrollment in an education program per canton $i$ in year $t$ is given by

$$
a_{i t}=v_{i}+\mathbf{x}_{i t}^{\prime} \beta+\varepsilon_{i t}
$$

where $v_{i}$ is a canton-specific term measuring unobserved heterogeneity which might be correlated with the regressors, $\mathbf{x}_{i}$ and $\beta$ are vectors and the error term is $\varepsilon_{i t}$. The regressors include business cycle variables and demographic variables as described above.

We apply a first-differences estimator in order to difference out any cantonspecific unobserved effects. The differences in new apprenticeship contracts between period $t$ and period $t-1$ are given by

$$
\left(a_{i t}-a_{i, t-1}\right)=\left(\mathbf{x}_{i t}-\mathbf{x}_{i, t-1}\right)^{\prime} \beta+\left(\varepsilon_{i t}-\varepsilon_{i, t-1}\right)
$$

To obtain consistent estimates, it is required that

$$
E\left[\left(\varepsilon_{i t}-\varepsilon_{i, t-1}\right) \mid\left(\mathbf{x}_{i t}-\mathbf{x}_{i, t-1}\right)\right]=0
$$

This is somewhat weaker than the strong exogeneity condition which would be required to estimate a fixed effects model, where $E\left[\varepsilon_{i t} \mid \mathbf{x}_{i 1}, \ldots, \mathbf{x}_{i T}\right]=0$. We estimate first-differences using FGLS, assuming that $\varepsilon_{i t}$ are i.i.d. $\left[0, \sigma_{\varepsilon}^{2}\right]$. This means that the error $\left(\varepsilon_{i t}-\varepsilon_{i, t-1}\right)$ is an $\mathrm{MA}(1)$ error with variance $2 \sigma_{\varepsilon}^{2}$ and a one-period apart autocovariance $\sigma_{\varepsilon}^{2}$ for cantons $i$.

\section{Results}

This section presents results for the impact of the business cycle variables separately on yearly changes in apprenticeship contracts, yearly changes in high school enrollment and as well on yearly changes in the ratio of apprenticeships to high school enrollment. In addition, we also consider the effects of demographic changes on our variables of interest.

\subsection{Business cycle effects}

Our results show that changes in the business cycle significantly impact the number of apprenticeship contracts in a given year. An increase in the unemployment rate leads to a decrease in new apprenticeship contracts (Table 2). As unemployment is inversely related to the tightness of the labor market. This result can be interpreted such that firms are more likely to offer apprenticeship programs in a situation of a tight labor market. While the coefficient is statistically highly significant, the economic impact is rather small. An decrease in the unemployment rate of $1 \%$-point 
from one year to the next leads to an increase of roughly 14 new apprenticeship contracts in a canton on average, which is equal to an increase of $0.6 \%$. Put differently, one standard deviation decrease in the unemployment rate (i.e. 1.86\%-points) leads to an increase in new apprenticeship contracts of roughly $1 \%$, et vice versa.

The effect of an increase in the growth rate of the (lagged) cantonal income is positive, but only marginally significant depending on the model specification. The economic magnitude of the effect is, however, negligible. This is not surprising, because we expect that the firm's decision to offer apprenticeship programs is more closely tied to the situation on the labor market than the overall economic climate.

Enrollment in high school does not depend on the business cycle. Neither the unemployment rate nor the growth rate in cantonal income have any significant effects (Table 3). In theory, both a negative or a positive impact of the business cycle on high school enrollment rates are possible. The fact that high school enrollment does not react positively to business cycles indicates that high schools apply entry standards that are independent of the situation on the labor market. At the same time, the results also show that in the short-run, business cycle fluctuations do not seem to affect short-run public funding of high school institutions, even though budget cuts frequently occur during recessions in other areas of public spending.

So far, we have estimated business cycle effects separately for new apprenticeships and high school enrollment. However, one could imagine that unobserved effects influencing the decision to enroll in these programs might be correlated across the two equations. To circumvent this (potential) problem, we also estimate the ratio of apprenticeships to high school enrollment. The results show that this ratio, as expected, is also negatively influenced by the unemployment rate (Table 4). One standard deviation increase in the unemployment rate leads to a decrease of the apprenticeships to high school enrollment ratio of roughly $2 \%$. This result is qualitatively comparable to the effects described above.

\subsection{Demographic effects}

The population of young people at age 16 in a given canton has a significant and positive effect on new apprenticeships (Table 2). An increase in a cohort of school leavers by 10 leads to 2.7 new apprenticeships, holding other factors constant. This number might seem very low at first sight, however, to give it a meaningful interpretation, one has to consider that on average, only $55 \%$ of a cohort of school leavers chooses a dual apprenticeship. Hence, training firms expand their relative offer for apprenticeships by roughly $50 \%$ for each additional school leaver. ${ }^{8}$ This results is also of economic significance, because demographic fluctuations have been rather strong in the past. A one standard deviation increase in the population of 16 year

\footnotetext{
${ }^{8}$ In many years of our period of observation, the supply of school leavers has exceeded the firm's demand for apprentices, leaving a significant fraction of young people without an apprenticeship. However, such individuals often successfully enroll in an apprenticeship program in the subsequent year. This is a further reason why firms cannot react proportionally to current changes in the populations, as there is always a supply surplus from the last period which fills part of the new apprenticeship positions.
} 
old leads to an increase in apprenticeships of $32 \%$ percent. Comparing this to the business cycle effects above, it can be concluded that demographic changes have a much stronger impact on new apprenticeships. Schweri \& Müller (2007) also report a substantial positive effect of 16-year old on training provision of firms in Switzerland.

In Switzerland, pupils usually have to make the decision to enroll in high school earlier before they have to search for an apprenticeship. In many cantons, pupils already enroll in junior high school in grade seven, which enables them to go on to senior high school without any further examinations. Therefore, the supply of apprentices to firms in a given year does not equal the entire population of 16-year old who leave compulsory schooling, but instead only those who have not already enrolled in high schools before. To test for this, we have included such a variable in the last two model specifications in Table 2 . However, the coefficient is not significantly different from the coefficient of the whole population of 16-year old. In addition, we have tested for the possibility that population growth could have a different impact on new apprenticeships compared to a decrease in the population. Again, the coefficients of a population increase and decrease, respectively, are not statistically different from each other.

Changes in the population of school leavers have, overall, a lower effect on high school enrollment, which is to be expected, since on average less than $20 \%$ of each cohort goes on to high school. An increase in the population of school leavers by 10 leads to an increase in high school enrollment by roughly 0.45 (Table 3 ). This means that compared to the average enrollment (which is equal to roughly $17 \%$ of a cohort) high schools expand by about $26 \%$. An increase by one standard deviation leads to an increase in high school enrollment of about $20 \%$. The model specifications in the last two columns show that high school enrollment reacts differently to increases than to decreases in the population. An increase in the population of school leavers by 10 leads to 1.09 new high school enrollments, which is equivalent to an relative increase of about $64 \%$. However, if the population shrinks, high schools do not reduce enrollment rates at all. Hence, our results suggest that high schools expand during times of a demographic boom, but that newly acquired infrastructure will not be reduced, once it is in place. ${ }^{9}$ Finally, it should be noted that overall population growth (all ages) has a positive effect on high school enrollment. An increase in the cantonal population by 1000 leads to an increase in high school enrollment of 3 pupils. This is in contrast to the effect on apprenticeships, where the effect is zero. However, it is in line with the financing of the respective education programs, since expansions in high school education have to be entirely financed through cantonal taxes, where apprenticeships are additionally financed by apprentices themselves, training firms and also partly by the federal government.

\footnotetext{
${ }^{9}$ This result receives some support from the estimations in Table 4. While the coefficient of overall population growth of 16-year old is virtually zero, the coefficient is positive for a population increase, but negative for a decrease (although only the latter coefficient being marginally significant at the $10 \%$-level).
} 
Table 2: Determinants of enrollment in apprenticeships

\begin{tabular}{|c|c|c|c|c|c|c|}
\hline Dependent variable: $\Delta$ Apprenticeships ${ }_{t, t-1}$ & $(1)$ & (2) & (3) & (4) & $(5)$ & $(6)$ \\
\hline$\Delta$ Unemployment $_{t, t-1}$ & -12.959 & -16.981 & -15.278 & -15.042 & -14.206 & -14.047 \\
\hline$\Delta$ National Income Growth ${ }_{t-1, t-2}$ & $\begin{array}{r}0.775 \\
(0.477)\end{array}$ & $\begin{array}{r}1.110 \\
(0.573)\end{array}$ & $\begin{array}{r}0.734 \\
(0.522)\end{array}$ & $\begin{array}{r}0.755 \\
(0.521)\end{array}$ & $\begin{array}{r}0.995 \\
(0.540)\end{array}$ & $\begin{array}{r}1.073 \\
(0.552)\end{array}$ \\
\hline$\Delta$ Population ${ }_{\text {Total }}^{\text {Age } 16}{ }_{t, t-1}$ & & & $\begin{array}{r}0.268 \\
(0.044)\end{array}$ & $\begin{array}{r}0.259 \\
(0.045)\end{array}$ & & \\
\hline$\Delta$ Population $\begin{array}{l}\text { Age } 16 \\
\text { Total } \\
t, t-1\end{array} \times \Delta$ Unemployment $_{t, t-1}$ & & & & $\begin{array}{r}0.052 \\
(0.052)\end{array}$ & & \\
\hline$\Delta$ Population ${ }^{\text {Total }}{ }_{t, t-1}$ & & & & $\begin{array}{r}-0.001 \\
(0.002)\end{array}$ & & \\
\hline$\Delta\left(\text { Population }_{\text {Total }}^{\text {Age } 16} \text { - Population }_{\text {High school }}^{\text {Age } 16}\right)_{t, t-1}$ & & & & & $\begin{array}{r}0.208 \\
(0.040)\end{array}$ & \\
\hline $\begin{array}{l}\Delta(\text { Population Age } 16 \\
\text { Total }\end{array}$ & & & & & & $\begin{array}{r}0.236 \\
(0.074)\end{array}$ \\
\hline $\begin{array}{l}\Delta(\text { Population Age } 16 \\
\text { Total }\end{array}$ & & & & & & $\begin{array}{r}0.184 \\
(0.058)\end{array}$ \\
\hline Trend 1988-1991 & & $\begin{array}{r}-19.527 \\
(3.371)\end{array}$ & $\begin{array}{r}-23.515 \\
(2.861)\end{array}$ & $\begin{array}{r}-13.684 \\
(3.079)\end{array}$ & $\begin{array}{r}-14.945 \\
(3.198)\end{array}$ & $\begin{array}{r}-15.037 \\
(3.339)\end{array}$ \\
\hline Trend 1992-2004 & & $\begin{array}{l}-0.043 \\
(0.951)\end{array}$ & $\begin{array}{l}-1.751 \\
(0.798)\end{array}$ & $\begin{array}{l}-0.603 \\
(0.812)\end{array}$ & $\begin{array}{l}-0.357 \\
(0.859)\end{array}$ & $\begin{array}{l}-0.263 \\
(0.905)\end{array}$ \\
\hline Constant & $\begin{array}{r}2.827 \\
(2.685)\end{array}$ & $\begin{array}{r}14.796 \\
(7.571)\end{array}$ & $\begin{array}{l}13.814 \\
(6.462)\end{array}$ & $\begin{array}{r}14.838 \\
(6.744)\end{array}$ & $\begin{array}{l}14.948 \\
(6.831)\end{array}$ & $\begin{array}{r}13.173 \\
(7.528)\end{array}$ \\
\hline Observations & 416 & 416 & 416 & 416 & 414 & 416 \\
\hline Number of cantons & 26 & 26 & 26 & 26 & 26 & 26 \\
\hline
\end{tabular}

Notes: Panel-robust standard errors in parentheses. 
Table 3: Determinants of enrollment in high schoool

\begin{tabular}{|c|c|c|c|c|c|}
\hline Dependent variable: $\Delta$ High school enrollment $t_{t, t-1}$ & $(1)$ & $(2)$ & (3) & $(4)$ & $(5)$ \\
\hline \multirow[t]{2}{*}{$\Delta$ Unemployment $_{t, t-1}$} & 2.701 & 2.828 & 2.901 & 1.706 & 1.834 \\
\hline & (1.934) & (1.963) & $(1.934)$ & $(1.692)$ & $(1.531)$ \\
\hline \multirow[t]{2}{*}{$\Delta$ National Income Growth ${ }_{t-1, t-2}$} & 0.279 & 0.278 & 0.262 & 0.260 & 0.211 \\
\hline & $(0.243)$ & $(0.245)$ & $(0.243)$ & $(0.215)$ & $(0.193)$ \\
\hline \multirow{2}{*}{$\Delta$ Population $\begin{array}{l}\text { Age } 16 \\
\text { Total }\end{array} t, t-1$} & & & 0.045 & 0.045 & \\
\hline & & & $(0.022)$ & $(0.022)$ & \\
\hline \multirow[t]{2}{*}{$\Delta$ Population ${ }^{\text {Total }}{ }_{t, t-1}$} & & & & 0.003 & 0.002 \\
\hline & & & & $(0.001)$ & $(0.001)$ \\
\hline \multirow[t]{2}{*}{$\Delta$ Population Age $16_{t, t-1}$ if $\Delta>0$} & & & & & 0.109 \\
\hline & & & & & $(0.036)$ \\
\hline \multirow[t]{2}{*}{$\Delta$ Population Age $16_{t, t-1}$ if $\Delta<0$} & & & & & -0.015 \\
\hline & & & & & $(0.035)$ \\
\hline \multirow[t]{2}{*}{ Trend } & & 0.127 & -0.050 & 0.114 & 0.074 \\
\hline & & $(0.319)$ & $(0.324)$ & $(0.271)$ & $(0.234)$ \\
\hline \multirow[t]{2}{*}{ Constant } & 6.376 & 4.170 & 7.075 & 1.227 & -0.151 \\
\hline & $(1.453)$ & (5.796) & (5.858) & $(5.058)$ & (4.380) \\
\hline Observations & 416 & 416 & 416 & 416 & 442 \\
\hline Number of cantons & 26 & 26 & 26 & 26 & 26 \\
\hline
\end{tabular}

Notes: Panel-robust standard errors in parentheses. 
Table 4: Apprenticeships/High school enrollment

\begin{tabular}{|c|c|c|c|c|c|}
\hline Dep. variable: $\Delta$ Apprenticeships / high school enrollment $t_{t,-1}$ & (1) & (2) & (3) & (4) & (5) \\
\hline$\Delta$ Unemployment $_{t, t-1}$ & -0.049 & -0.050 & -0.048 & -0.050 & -0.050 \\
\hline & $(0.015)$ & $(0.015)$ & $(0.015)$ & $(0.014)$ & $(0.014)$ \\
\hline$\Delta$ National Income Growth $_{t-1, t-2}$ & 0.000 & 0.002 & 0.002 & 0.003 & 0.002 \\
\hline & $(0.003)$ & $(0.003)$ & $(0.003)$ & $(0.003)$ & $(0.003)$ \\
\hline$\Delta$ Population Age $16{ }_{t, t-1}\left(\right.$ in $\left.{ }^{\prime} 000\right)$ & & & $\begin{array}{r}-0.049 \\
(0.125)\end{array}$ & $\begin{array}{r}-0.093 \\
(0.122)\end{array}$ & \\
\hline$\Delta$ Population $^{\text {Total }}{ }_{t, t-1}$ (in '000) & & & & $\begin{array}{r}0.005 \\
(0.005)\end{array}$ & $\begin{array}{r}0.003 \\
(0.004)\end{array}$ \\
\hline$\Delta$ Population Age $16_{t, t-1}$ if $\Delta>0$ (in '000) & & & & & $\begin{array}{r}0.143 \\
(0.176)\end{array}$ \\
\hline$\Delta$ Population Age $16_{t, t-1}$ if $\Delta<0$ (in '000) & & & & & $\begin{array}{r}-0.369 \\
(0.207)\end{array}$ \\
\hline Trend 1988-1991 & & $\begin{array}{r}-0.084 \\
(0.016)\end{array}$ & $\begin{array}{r}-0.085 \\
(0.016)\end{array}$ & $\begin{array}{r}-0.093 \\
(0.016)\end{array}$ & $\begin{array}{r}-0.091 \\
(0.016)\end{array}$ \\
\hline Trend 1992-2004 & & $\begin{array}{r}-0.001 \\
(0.004)\end{array}$ & $\begin{array}{r}-0.001 \\
(0.004)\end{array}$ & $\begin{array}{r}-0.002 \\
(0.004)\end{array}$ & $\begin{array}{r}-0.001 \\
(0.004)\end{array}$ \\
\hline Constant & $\begin{array}{r}-0.058 \\
(0.016)\end{array}$ & $\begin{array}{r}-0.023 \\
(0.038)\end{array}$ & $\begin{array}{r}-0.023 \\
(0.038)\end{array}$ & $\begin{array}{r}-0.029 \\
(0.039)\end{array}$ & $\begin{array}{r}-0.055 \\
(0.040)\end{array}$ \\
\hline Observations & 416 & 416 & 416 & 416 & 416 \\
\hline Number of cantons & 26 & 26 & 26 & 26 & 26 \\
\hline
\end{tabular}

Notes: Panel-robust standard errors in parentheses. 


\section{Conclusions}

In this paper we analyze business cycle effects on dual apprenticeship programs in 26 Swiss cantons from 1988-2004. Using first-differences panel estimators, we find that increases in the cantonal unemployment rate are negatively related to the number of new apprenticeship contracts in a given canton; a 1\%-point increase in the unemployment rate leads to $0.6 \%$ less apprenticeship contracts in a given year. Furthermore, lagged cantonal income growth has a significant and positive effect on apprenticeship provision. These findings are in line with theories explaining that firms are more willing to train apprentices in times of a tight labor market, such that apprenticeship training can be regarded as a way for firms to sustain a skilled workforce. However, the (combined) magnitude of these effects is rather small, indicating that (short-term) business cycle impacts on apprenticeship training are not the main driving force of the observed patterns in the number of yearly apprenticeship contracts. Interpreting these results, one should keep in mind that they are found in a country where apprenticeship training opportunities are more or less evenly spread across all sectors of economic activity and a majority of school-leavers apply for apprenticeship positions. Therefore, it might well be that business cycles have a more pronounced effect in countries where apprenticeship training is concentrated in specific industries or only attracts specific parts of the ability distribution of a cohort.

Compared to the impact of business cycles on apprenticeship training, we find evidence that demographic changes in the cohort of young people at age 16 have a much stronger (and positive) effect on apprenticeship enrollment; one additional school leaver leads a firm to increase their average demand for apprentices by $50 \%$. Similarly, alternative full-time education programs also react to demographic fluctuations, but not to business cycles. We find that a marginal increase in the population at age 16 leads to 0.045 new pupils enrolling in high school, which is equal to an increase of $26 \%$ compared to the average enrollment rate of 0.17 .

\section{References}

Askilden, J. E. \& Nilsen, O. A. (2005). Apprentices and young workers: A study of the Norwegian youth labour market. Scottish Journal of Political Economy, 52 (1), 1-17.

Bassanini, A., Booth, A., Brunello, G., De Paola, M. \& Leuven, E. (2007). Education and training in Europe. In Brunello, G., Garibaldi, P. \& Wasmer, E. (Eds.) Workplace Training in Europe. Oxford: Oxford University Press.

Bassanini, A. \& Brunello, G. (2007). Barriers to entry, deregulation and workplace training. IZA Discussion Papers No. 2746.

Bilginsoy, C. (2003). The hazards of training: Attrition and retention in construction industry apprenticeship programs. Industrial and Labor Relations Review, 57 (1), 54-67.

Blatter, M., Muehlemann, S. \& Schenker, S. (2008). The costs of hiring skilled workers. Economics of Education Working Paper Series No. 15.

Brunello, G. (2009). The effect of economic downturns on apprenticeships and initial workplace training: A review of the evidence. Paris: OECD.

Brunello, G. \& Medio, A. (2001). An explanation of international differences in education and workplace training. European Economic Review, 45 (2), 307-322. 
Dietrich, H. \& Gerner, H.-D. (2007). The determinants of apprenticeship training with particular reference to business expectations. Zeitschrift für ArbeitsmarktForschung; Journal for Labour Market Research, 40 (2/3), 221-233.

Dustmann, C. \& Schönberg, U. (2007). Apprenticeship training and commitment to training provision. Economics of Education Working Paper Series No. 32.

Federal Office for Professional Education and Technology (2008). Vocational education and training in Switzerland 2008 - Facts and figures. Berne: Federal Office for Professional Education and Technology.

Gielen, A. C. \& van Ours, J.C. (2006). Age-specific cyclical effects in job reallocation and labor mobility. Labour Economics, 13 (4), 493-504.

Hart, R. A. (2005). General human capital and employment adjustment in the great depression: Apprentices and journeymen in UK engineering. Oxford Economic Papers, 57 (1), 169-89.

Hoeckel, K., Field, S. \& Grubb, W. N. (2009). Learning for jobs. OECD Reviews of Vocational Education and Training - Switzerland. Paris: OECD.

Lindley, R. M. (1975). The demand for apprentice recruits by the engineering industry, 1951-71. Scottish Journal of Political Economy, 22(1), 1-24.

Majumdar, S. (2007). Market conditions and worker training: How does it affect and whom? Labour Economics, 14 (1), 1-23.

Merrilees, W. J. (1983). Alternative models of apprentice recruitment: With special reference to the British engineering industry. Applied Economics, 15 (1), 1-21.

Muehlemann, S., Schweri, J., Winkelmann, R. \& Wolter, S. C. (2007). An empirical analysis of the decision to train apprentices. Labour, 21 (3), 419-441.

Ryan, Paul (1998). Is apprenticeship better? A review of the economic evidence. International Journal of Training and Development, 50 (2), 289-325.

Schweri, J. \& Müller, B. (2008). Die Ausbildungsbereitschaft der Betriebe: Entwicklungen 1995 bis 2005. Neuchâtel: Bundesamt für Statistik.

Schweri, J. \& Müller, B. (2007). Why has the share of training firms declined in Switzerland? Zeitschrift für ArbeitsmarktForschung; Journal for Labour Market Research, 40 (2/3), 149-167.

Stevens, M. (1994). An investment model for the supply of training by employers. Economic Journal, 104 (424), 556-70.

Westergaard-Nielsen, N. \& Rasmussen, A. R. (1999). The impact of subsidies on the number of new apprentices. Research in labor economics, 18, 359-75.

Wolter, S. C., Muehlemann, S. \& Schweri, J. (2006). Why some firms train apprentices and many others do not. German Economic Review, 7(3), 249-264. 